\title{
Structural and photophysical properties of hydroxyapatite doped with lanthanide ions
}

\author{
Propriedades estruturais e fotofísicas da \\ hidroxiapatita dopada com íons lantanídeos
}

\author{
Amanda Alves Barbosa ${ }^{1,2}$, Severino Alves Junior ${ }^{1}$, \\ Raquel Aline Pessoa Oliveira ${ }^{2}$, Andréa de Vasconcelos Ferraz ${ }^{2}$
}

\footnotetext{
${ }^{1}$ Universidade Federal de Pernambuco - Av. Jorn. Aníbal Fernandes, s/nº Cidade Universitária, Recife, PE, Brasil.

${ }^{2}$ Universidade Federal do Vale do São Francisco - Av. Antonio Carlos Magalhaes 310, Juazeiro, BA, Brasil. e-mail: amanda.barbosa@univasf.edu.br, salvesjr@ufpe.br, raquel.oliveira@univasf.edu.br, andrea.ferraz@univasf.edu.br.
}

\section{RESUMO}

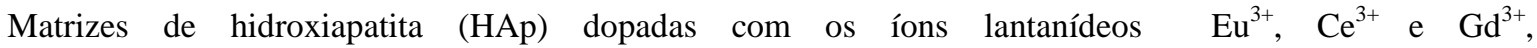
$\left[\mathrm{Ca}_{10-\mathrm{x}} \mathrm{Ln}_{\mathrm{x}}\left(\mathrm{PO}_{4}\right)_{6}(\mathrm{OH})_{2}\right]$, foram obtidas pelo método da precipitação com o objetivo de estudar suas propriedades fotofísicas. A partir de análises de Microscopia Eletrônica de Varredura observou-se que amostras dopadas com íons lantanídeos $\left(\mathrm{Ln}^{3+}\right)$ apresentaram similaridade com a morfologia da HAp pura, por outro lado nos difratogramas de Raios X a partir do refinamento Rietveld verificou-se que a matriz aparece como fase majoritária $(\approx 70 \%)$ enquanto $(\approx 30 \%)$ de uma fase secundária de tricálcio fosfato $(\mathrm{TCP})$ foi conferida em função das diferentes dopagens. Isotermas de adsorção obtidas pela técnica BET indicaram que todos os materiais sintetizados são classificados como mesoporosos. Os espectros de emissão dos materiais exibem bandas características dos íons $\mathrm{Ln}^{3+}$ incorporados à estrutura da matriz em $573 \mathrm{~nm}\left({ }^{5} \mathrm{D}_{0} \rightarrow \mathrm{F}_{0}\right), 600 \mathrm{~nm}\left({ }^{5} \mathrm{D}_{0} \rightarrow \mathrm{F}_{1}\right)$, $628 \mathrm{~nm}\left({ }^{5} \mathrm{D}_{0} \rightarrow \mathrm{F}_{2}\right)$, e $698 \mathrm{~nm}\left({ }^{5} \mathrm{D}_{0} \rightarrow \mathrm{F}_{4}\right)$ para HAp/Eu, 337-360 nm $(5 \mathrm{~d} \rightarrow 4 \mathrm{f})$ para HAp/Ce e em $425 \mathrm{~nm}$ para $\mathrm{HAp} / \mathrm{Gd}$.

Palavras-chave: Hidroxiapatita; Compósito; Luminescente; Biomaterial; Propriedades.

\begin{abstract}
Hydroxyapatite (HAp) matrices doped with lanthanide ions $\mathrm{Eu}^{3+}$, $\mathrm{Ce}^{3+}$ and $\mathrm{Gd}^{3+}$, $\left[\mathrm{Ca}_{10-\mathrm{x}} \mathrm{Ln}_{\mathrm{x}}\left(\mathrm{PO}_{4}\right)_{6}(\mathrm{OH})_{2}\right]$ were obtained through the precipitation method so their photophysical properties could be studied. From the Scanning Electron Microscopy analyzes it was observed that samples doped with lanthanide ions $\left(\mathrm{Ln}^{3+}\right)$ showed similarity with the morphology of pure HAp, whereas Rietveld-refined X-ray diffractograms showed that the matrix appears as the major phase $(\approx 70 \%)$ while $(\approx 30 \%)$ of a second phase of tricalcium phosphate (TCP) was due to the different doping levels. Adsorption isotherms obtained by the BET technique indicated that all the synthesized materials are classified as mesoporous. The emission spectra of the materials exhibit bands typical of the $\mathrm{Ln}^{3+}$ ions incorporated into the matrix structure at $573 \mathrm{~nm}$ $\left({ }^{5} \mathrm{D}_{0} \rightarrow \mathrm{F}_{0}\right), 600 \mathrm{~nm}\left({ }^{5} \mathrm{D}_{0} \rightarrow \mathrm{F}_{1}\right), 628 \mathrm{~nm}\left({ }^{5} \mathrm{D}_{0} \rightarrow \mathrm{F}_{2}\right)$, and $698 \mathrm{~nm}\left({ }^{5} \mathrm{D}_{0} \rightarrow \mathrm{F}_{4}\right)$ for HAp/Eu, 337-360 nm $(5 \mathrm{~d} \rightarrow 4 \mathrm{f})$ for $\mathrm{HAp} / \mathrm{Ce}$ and at $425 \mathrm{~nm}$ for $\mathrm{HAp} / \mathrm{Gd}$.
\end{abstract}

Keywords: Hydroxyapatite; Composite; Luminescent; Biomaterial; Properties.

\section{INTRODUCTION}

The mineral apatite, $\mathrm{Ca}_{5}\left(\mathrm{PO}_{4}\right)_{3} \mathrm{X}_{2}(\mathrm{X}=\mathrm{F}, \mathrm{OH}, \mathrm{Cl})$, is the most abundant natural phosphate on Earth. Its chemical structure contains many replacements between cations and anions - practically half of the periodic table can be incorporated to its atomic arrangement, which is one of the most interesting properties of apatites [1]. In biological systems, the apatite variety called hydroxyapatite, $\mathrm{Ca}_{10}\left(\mathrm{PO}_{4}\right)_{6}(\mathrm{OH})_{2}$, consists of the major mineral component of bones and teeth [2]. Because of its high chemical and crystallographic similarity to the 
bone structure, synthetic HAp is considered a bioactive substance, since it binds strongly to the host bone tissue. In addition, it is a biocompatible, osteoconductive, non-immunogenic and non-toxic material [3]. These characteristics make HAp a suitable biomaterial for medical applications, with it being widely used as bone grafts and highly promising for clinical use [3].

The replaced apatites are generally produced by synthesis; in the case of HAp, different routes are used in their production such as the reaction sol-gel $[4,5]$, microwave irradiation $[6,7]$ and precipitation reaction $[8,9]$, the latter being the most used. The ease of performing ionic exchanges in the HAp structure can be attributed to its broad surface area, besides the existence of a metastable hydrate layer on the surface of the nanocrystals whose ionic bonds are weak [10, 11].

Considering the characteristics presented by HAp as a good host material, the introduction of trivalent lanthanide ions $\left(\mathrm{Ln}^{3+}\right)$, due to its optical properties and great applicability, has aroused the interest of several research groups. ZENG et al. [12] developed a polymeric biosensor doped with $\mathrm{Ce}^{3+}$ and $\mathrm{Tb}^{3+}$ ions capable of detecting $\mathrm{H}_{2} \mathrm{O}_{2}$, indicating potential for use in the determination of glucose. CANTARELLI et al. [13] proposed the incorporation of $\mathrm{Gd}^{3+}, \mathrm{Yb}^{3+}, \mathrm{Er}^{3+}$ and $\mathrm{Gd}^{3+}, \mathrm{Yb}^{3+}, \mathrm{Tm}^{3+}$ ions in $\mathrm{CaF}_{2}$ nanoparticles producing biocompatible nanoprobes for biomedical images, which were efficient for surgical applications. In our research group, various studies involving the spectroscopic study of materials containing lanthanide ions have already been developed, such as SOUZA et al. [14]. The authors carried out the doping of a polymer with Eu (III) and $\mathrm{Tb}$ (III) complexes and obtained red and green solid state emitters. LIMA et al. [15] synthesized complexes of lanthanide ions $\left(\mathrm{Eu}^{3+}, \mathrm{Tb}^{3+}\right.$ and $\left.\mathrm{Gd}^{3+}\right)$ with ligands derived from dicarboxylic acids to study the effect of the substituents on the luminescence of lanthanide ions in the $\mathrm{Eu}^{3+}$ and $\mathrm{Tb}^{3+}$ complexes.

Thus, the objective of the present work was to evaluate the incorporation of different $\mathrm{Ln}^{3+}$ ions into an inorganic matrix (HAp) and to study its photophysical properties for the development of a luminescent biomaterial with potential for application in the medical field.

\section{MATERIALS AND METHODS}

\subsection{Materials}

The following analytical grade chemical reagents were used in the synthesis of doped $\mathrm{HAp}:\left(\mathrm{NH}_{4}\right)_{2} \mathrm{HPO}_{4}$ (Vetec), $\mathrm{NH}_{4} \mathrm{OH}$ (Scientific Exodus), $\mathrm{HCl}$ (Vetec), $\mathrm{Eu}_{2} \mathrm{O}_{3}, \mathrm{Gd}_{2} \mathrm{O}_{3}$ and $\mathrm{Ce}_{2} \mathrm{O}_{3}$ (Sigma-Aldrich). The source of calcium used was gypsum $\beta, \mathrm{CaSO}_{4} \cdot 1 / 2 \mathrm{H}_{2} \mathrm{O}$, with a $80-95 \%$ purity, provided by Industrial Mineral Gypsum Ltda.

\subsection{Synthesis of the Hydroxyapatite Matrix}

Hydroxyapatite was obtained by the precipitation method [16], with a molar ratio of $1.66 \mathrm{Ca} / \mathrm{P}$, according to the reaction represented by equation (1).

$$
\begin{aligned}
& 10 \mathrm{CaSO}_{4} \frac{1}{2} \mathrm{H}_{2} \mathrm{O}+6\left(\mathrm{NH}_{4}\right)_{2} \mathrm{HPO}_{4}+8 \mathrm{NH}_{4} \mathrm{OH} \rightarrow \mathbf{C a}_{10}\left(\mathbf{P O}_{4}\right)_{6}(\mathbf{O H})_{2}+10\left(\mathrm{NH}_{4}\right)_{2} \mathrm{SO}_{4}+11 \mathrm{H}_{2} \mathrm{O} \\
& \text { Hydroxyapatite }
\end{aligned}
$$

Initially, $250 \mathrm{~mL}$ of a $0.1 \mathrm{~mol} . \mathrm{L}^{-1} \mathrm{CaSO}_{4} \cdot 1 / 2 \mathrm{H}_{2} \mathrm{O}$ solution was placed under stirring and then a 3.0 mol.L $\mathrm{L}^{-1} \mathrm{NH}_{4} \mathrm{OH}$ solution was added until $\mathrm{pH}=10$. Subsequently, $250 \mathrm{~mL}$ of a $0.06 \mathrm{~mol} . \mathrm{L}^{-1}\left(\mathrm{NH}_{4}\right)_{2} \mathrm{HPO}_{4} \mathrm{So}^{-}$ lution was added at a flow rate of $20 \mathrm{~mL} \cdot \mathrm{min}^{-1}$. The $\mathrm{pH}$ was maintained around 10 through the addition of 3.0 mol. $\mathrm{L}^{-1} \mathrm{NH}_{4} \mathrm{OH}$ until the end of the synthesis. After the addition of all reagents, the system remained under magnetic stirring for one hour for complete homogenization of the mixture. Then, the system stood still for the sedimentation of the denser component. The material produced was vacuum-filtered and washed with deionized water until neutral $\mathrm{pH}$ and then oven-dried at $100{ }^{\circ} \mathrm{C}$ for 24 hours. The dried material was triturated and then calcined at $900{ }^{\circ} \mathrm{C}$ for 2 hours with a heating rate of $10^{\circ} \mathrm{C} \cdot \mathrm{min}^{-1}$.

\subsection{Synthesis of the Doped Hydroxyapatite Matrix with Lanthanide ions}

The process of synthesis of the HAp doped with lanthanide ions followed the same methodology used in the preparation of pure HAp. For each of the doped materials, HAp/Eu, HAp/Ce and HAp/Gd, $2.0 \%$ of the molar amount of $\mathrm{Ca}^{2+}$ ions was replaced by the respective $\mathrm{Ln}^{3+}$ ion in the form of chlorides. The addition was made during the stirring step of calcium sulphate, following the same procedures described in item 2.1.2. 


\subsection{Characterizations}

The synthesized materials were characterized by several techniques, such as Scanning Electron Microscopy with X-ray Dispersive Energy Analysis (Hitachi TM1000 and Vega 3 Tescan) used to observe the sample morphology. The structure of the materials was characterized by infrared spectra obtained by FTIR equipment, Model: Spectrum Two, in the range of $4000-400 \mathrm{~cm}^{-1}$ wave numbers. Samples were prepared as $\mathrm{KBr}$ pellets using mechanical pressing.

The analysis of the crystalline phases was done by X-ray diffraction (XRD) with the Difract ACT 1000 series (Siemens), using the copper $\mathrm{k} \alpha$ line $(\lambda=1.54056 \AA)$ at $40 \mathrm{kV}$ and $40 \mathrm{~mA}$. The $2 \theta$ range was $20^{\circ}$ to $50^{\circ}$, with a step of $0.02^{\circ}$ and integration time of $1 \mathrm{~s}$ per point. Phase identification was confirmed using the Rietveld method employed X'Pert HighScore Plus software version 2.0a. The experimental XRD pattern was compared to the parameters of ICSD 16742 reference sheets corresponding to HAp $\left(\mathrm{Ca}_{10}\left(\mathrm{PO}_{4}\right)_{6}(\mathrm{OH})_{2}\right)$, belonging to the hexagonal crystal system, and to the spatial group P63/ m. The crystallographic parameters were: $\mathrm{a}=9.4320 \AA, \mathrm{b}=9.4320 \AA, \mathrm{c}=6.8810 \AA, \alpha=90^{\circ}, \beta=90^{\circ}$ and $\gamma=120^{\circ}$ and ICSD 6191 corresponds to Tricalcium Phosphate (TCP) $\left(\mathrm{Ca}_{3}\left(\mathrm{PO}_{4}\right)_{2}\right)$, belonging to the rhombohedral crystal system, and the space group R3c. The crystallographic parameters were: $\mathrm{a}=10.4390 \AA, \mathrm{b}=10.4390 \AA, \mathrm{c}=37.3750 \AA, \alpha=90^{\circ}, \beta=90^{\circ}$ and $\gamma=120^{\circ}$.

The Brunauer-Emmett-Teller (BET) surface area measurements were performed by the Micrometrics ASAP 2420 surface area analyzer. The photoluminescent properties of the solid-state materials were investigated in a Jobin-Yvon Ramanor U-1000 double-monochromator spectrofluorometer. For excitation, a JobinYvon monochromator model $\mathrm{H}-10$ was used, using a Xe-Hg lamp (150W).

\section{RESULTS AND DISCUSSION}

The FTIR spectra for both pure HAp and HAp doped with the different lanthanide ions are shown in Figure 1. As observed, HAp/Eu, HAp/Ce and HAp/Gd have the same spectral profiles. Vibrations of 569 to $609 \mathrm{~cm}^{-}$ ${ }^{1}$ are attributed to O-P-O $\left(\vee_{4}\right)$ deformation in $\mathrm{PO}_{4}{ }^{3-}$ or angular deformation O-P-O $\left(\vee_{4}\right)$ in $\mathrm{HPO}_{4}{ }^{2} ; 954$ to 956 $\mathrm{cm}^{-1}$ for symmetrical stretching $\mathrm{P}-\mathrm{O}\left(\mathrm{V}_{1}\right)$ of the $\mathrm{PO}_{4}{ }^{3-}$ group; 1032 to $1100 \mathrm{~cm}^{-1}$ for asymmetric stretching of $\mathrm{PO}_{4}{ }^{3-}\left(\mathrm{V}_{3}\right)$ or stretching $\mathrm{PO}_{3}\left(\mathrm{~V}_{6}\right)$ in $\mathrm{HPO}_{4}{ }^{2-}$; low intensity bands were verified at 1630 to $1633 \mathrm{~cm}^{-1}$ corresponding to the deformation $\mathrm{H}-\mathrm{O}-\mathrm{H}$ indicating the presence of $\mathrm{H}_{2} \mathrm{O} ; 636$ to $643 \mathrm{~cm}^{-1}$ are $\mathrm{OH}^{-}$hydroxyl vibrations and 3575 to $3579 \mathrm{~cm}^{-1}$ for hydroxyl $\mathrm{OH}^{-}\left(\vee_{5}\right)$ stretching, in accordance with the standards verified by YANG et al. [17].

The presence of $\mathrm{OH}^{-}$groups found in the samples indicates that HAp has binding sites suitable for incorporation of drug molecules; therefore, the material presents an important property for its use as a support for drugs [18].

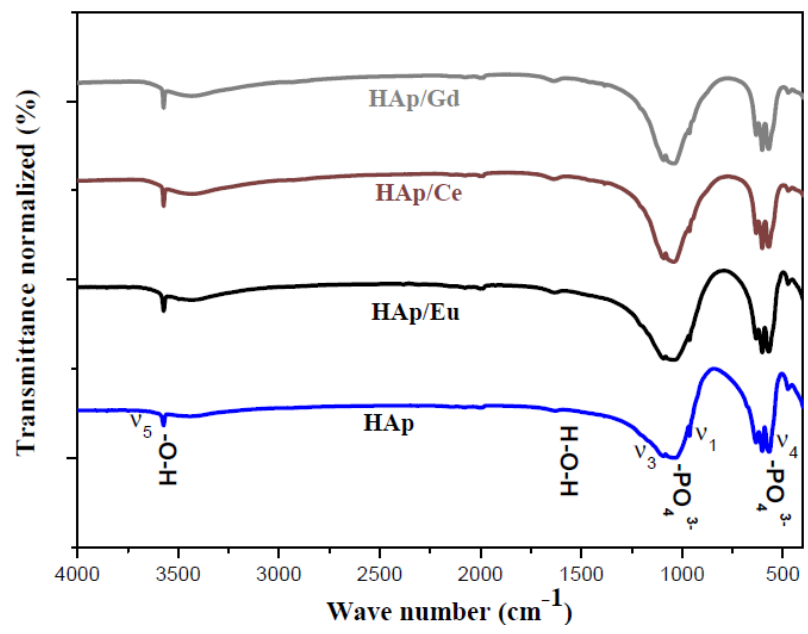

Figure 1: FTIR spectra of the materials HAp, HAp/Eu, HAp/Ce and HAp/Gd.

Figure 2 shows the powder XRD pattern obtained for the samples: HAp/Eu, HAp/Gd and HAp/Ce, where it can be seen that HAp is the major phase; however, the incorporation of lanthanide ions into the matrix structure caused the appearance of a peak at $2 \theta=31.0^{\circ}$ attributed to phosphate tricalcium phase (TCP). It was verified that the appearance of this phase can be explained by the introduction of the $\mathrm{Ln}^{3+}$ ions in the HAp lattice, which occurs by replacing the $\mathrm{Ca}^{2+}$ ions in two different crystallographic sites of the unit cell, turning it into $\mathrm{Ca}_{10-\mathrm{x}} \mathrm{Ln}_{\mathrm{x}}\left(\mathrm{PO}_{4}\right)_{6}(\mathrm{OH})_{2}$, [19] as shown in Figure 3. 

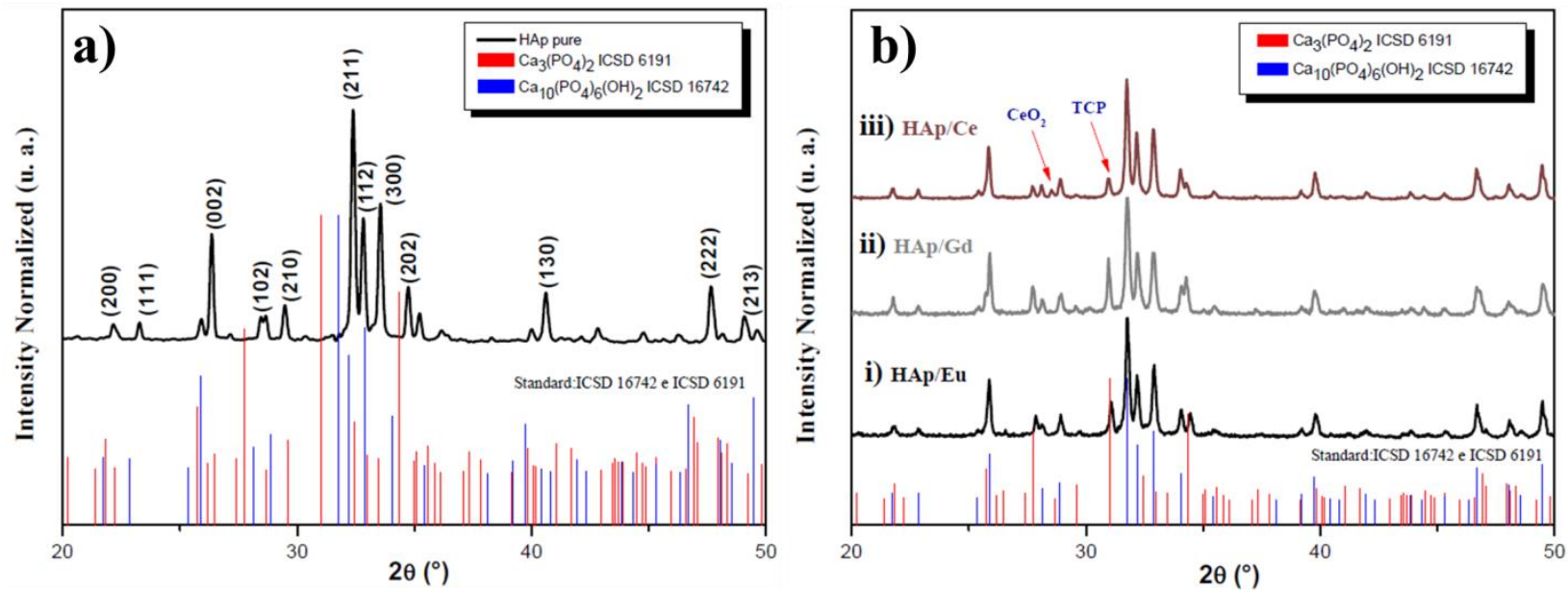

Figure 2: Experimental X ray powder diffraction patterns of a) HAp pure and b) (i) HAp/Eu, (ii) HAp/Gd, (iii) HAp/Ce and standards of reference sheets ICSD 16742 (HAp), ICSD 6191 (TCP).

The unit cell of HAp in the hexagonal phase has 10 calcium ions at two different non-equivalent crystallographic sites. Of these, four ions are at site I (Ca1) and another six located at site II (Ca2). The incorporation of the $\mathrm{Ln}^{3+}$ ions: $\mathrm{Eu}^{3+}, \mathrm{Ce}^{3+}$ and $\mathrm{Gd}^{3+}$ into the HAp structure of can occur through the occupation of both sites [21], Figure 3-b.

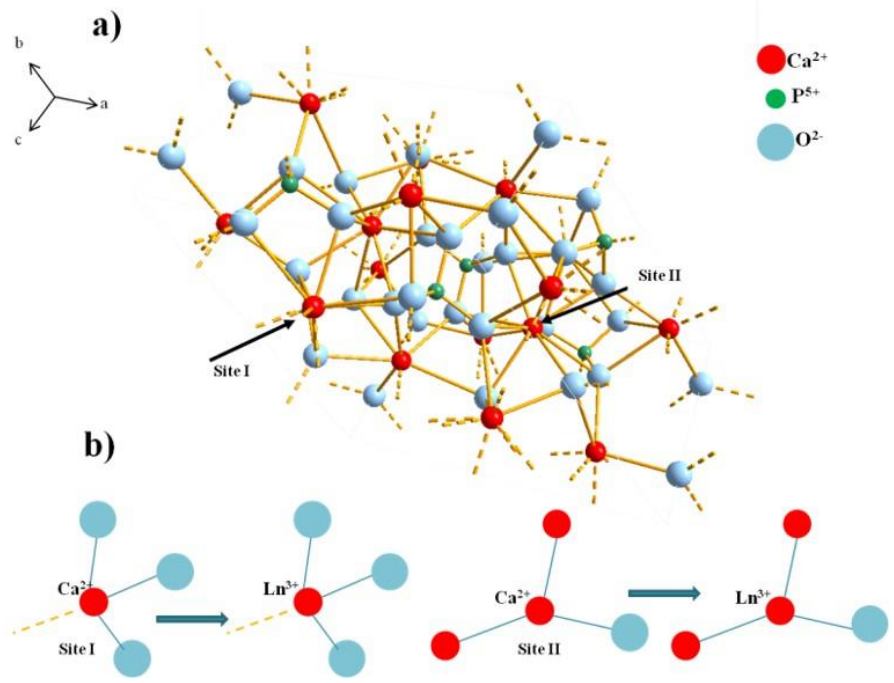

Figure 3: a) Representation of the two different cationic sites occupied by the $\mathrm{Ca}^{2+}$ ions in the hydroxyapatite and b) Substitution of the $\mathrm{Ln}^{3+}$ ions at the respective $\mathrm{Ca}^{2+}$ sites. Crystalline HAp cell obtained with X'Pert HighScore Plus software version $2.0 \mathrm{a}$.

The mechanism of charge compensation for the substitution of $\mathrm{Ca}^{2+}$ by $\mathrm{Ln}^{3+}$ in the HAp molecule in addition to the heat treatment can result in destabilization of the structure and formation of the TCP phase [22]. The presence of a second phase in the HAp causes an increase in its rate of degradation, and may be an important characteristic for its application in the medical field [23].

In the HAp/Ce diffractogram, a peak observed in $2 \theta=28.5^{\circ}$ was not compatible with HAp and also did not appear for $\mathrm{HAp} / \mathrm{Eu}$ and $\mathrm{HAp} / \mathrm{Gd}$. From the Ritveld refinement data, it was possible to identify the peak attributed to cerium oxide $\left(\mathrm{CeO}_{2}\right)$, indicating that $\mathrm{Ce}^{3+}$ ions were not thoroughly incorporated into the matrix structure. Comparing the ionic rays of $\mathrm{Ca}^{2+}$ to those of the dopants, $\mathrm{Ca}^{2+}=0.106 \mathrm{~nm}, \mathrm{Eu}^{3+}=0.098$ $\mathrm{nm}, \mathrm{Ce}^{3+}=0.107 \mathrm{~nm}$ and $\mathrm{Gd}^{3+}=0.097 \mathrm{~nm}$ [24], it is observed that $\mathrm{Eu}^{3+}$ and $\mathrm{Gd}^{3+}$ occupy the vacancies generated by the $\mathrm{Ca}^{2+}$ ions more easily because their rays are smaller. On the other hand, the ionic ray of $\mathrm{Ce}^{3+}$ is very close, but higher than that of $\mathrm{Ca}^{2+}$, and may limit its incorporation into the HAp lattice. MORAIS et al. [25] identified characteristic peaks for crystalline cerium oxide in the same region for the sample of HAp 
doped with the ion, confirming the results obtained in the diffractogram of Figure 2-b (iii). The influence of the dopants on the appearance of TCP in the material was proven by the quantification of the phases present for each of the samples. According to Table 01, that the values of HAp/Eu and HAp/Gd are very close to the TCP phase, whereas HAp/Ce presents a considerably lower value, demonstrating the complete nonincorporation of the $\mathrm{Ce}^{3+}$ ions into the HAp lattice.

Table 1: Percentage of phases depending on the different doping of the material.

\begin{tabular}{c|c|c}
\hline SAMPLE & \multicolumn{2}{|c}{ PHASES (\%MASS) } \\
\hline & HAP & TCP \\
\hline $\mathrm{HAp} / \mathrm{Eu}$ & 64.40 & 35.60 \\
\hline $\mathrm{HAp} / \mathrm{Ce}$ & 90.87 & 9.13 \\
\hline $\mathrm{HAp} / \mathrm{Gd}$ & 70.33 & 29.67 \\
\hline
\end{tabular}

Micrographs of pure HAp are shown in Figure 4, where particles with round shapes and uniform distribution are observed for the non-calcined material, Figure 4-a. For the calcined HAp, the morphology shows changes as a function of the heat treatment; in this case, the particles start a mass diffusion process, causing their size to increase and a change in their shape due to grain growth [9]. GYORGY et al. [26] and KAMALATHAN et al. [27] observed the densification of HAp powders due to the growth of grains attributed to the diffusion of the particles as a function of the sintering temperature.
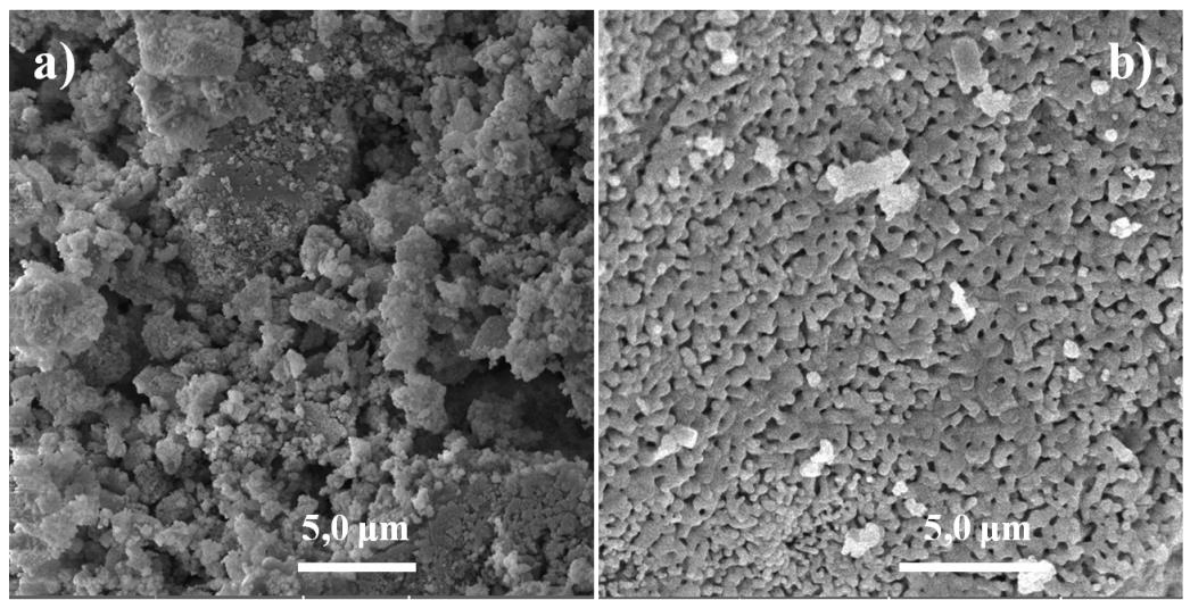

Figure 4: SEM micrographs of samples of HAp pure (a) not calcined and (b) after calcination.

In Figure 5, micrographs of the samples of HAp doped with $\mathrm{Ln}^{3+}$ ions are observed. The images of the samples doping with $\mathrm{Eu}^{3+}$ and $\mathrm{Ce}^{3+}$, (Figures 5-a and 5-c) show similarity between their morphologies and that observed for the matrix. However, spherical particle clusters were observed for the HAp/Gd sample, Figure 5-e. Also shown in Figure 5 are the EDS spectra for the various samples. In addition to the identification of the main elements that compose HAp as calcium $(\mathrm{Ca})$ and phosphorus $(\mathrm{P})$, doping is confirmed from the low intensity peaks attributed to $\mathrm{Ln}^{3+}$ ions: $\mathrm{Eu}^{3+}, \mathrm{Ce}^{3+} \mathrm{e} \mathrm{Gd}^{3+}$ incorporated into the HAp structure. The carbon-associated peak is due to the carbon tape used to fix the sample to the sample holder. 

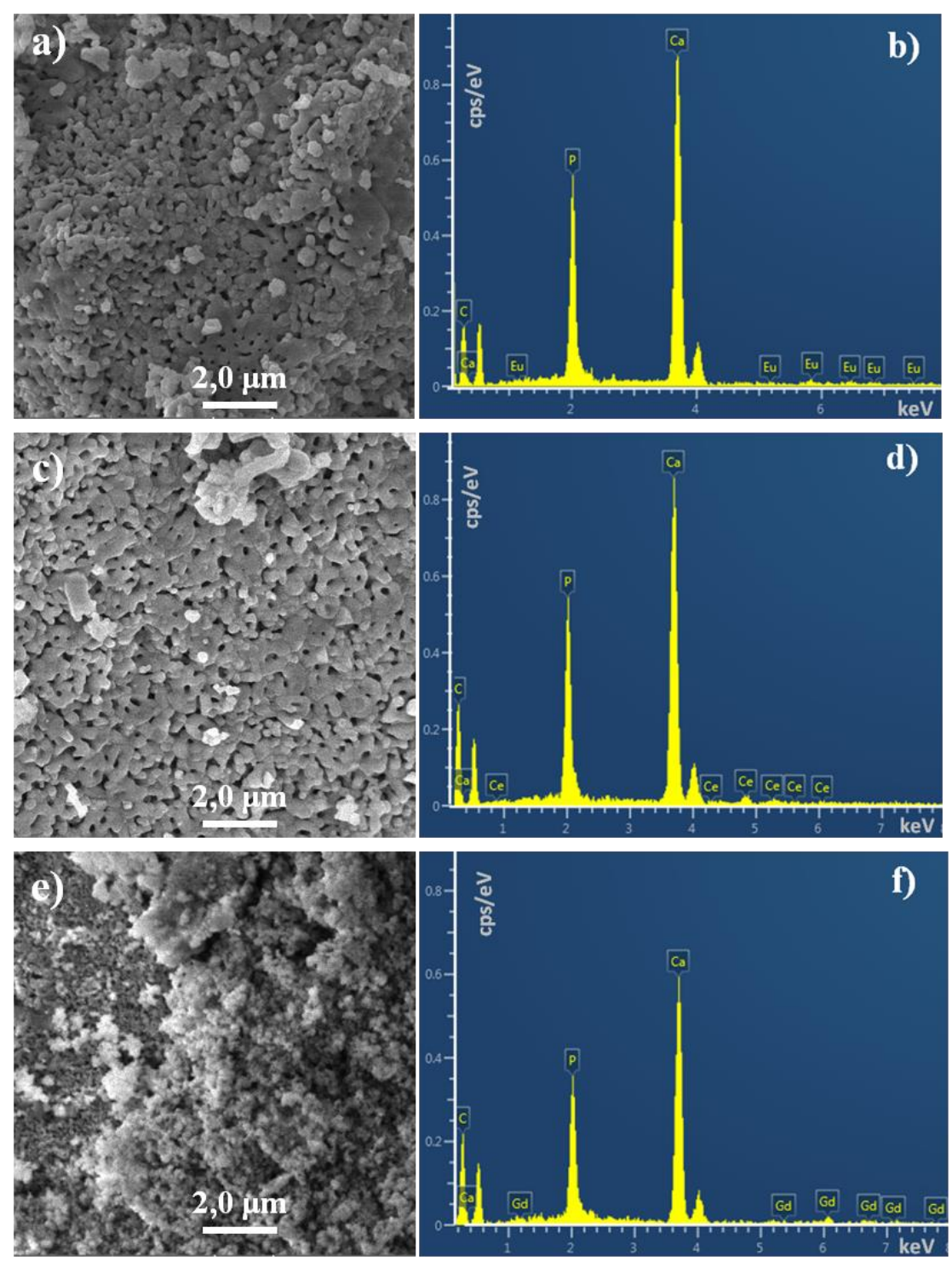

Figure 5: Micrographs obtained by scanning electron microscopy of the matrices of $\mathrm{HAp}$ doped with $\mathrm{Eu}^{3+}, \mathrm{Ce}^{3+}$ and $\mathrm{Gd}^{3+}$ ions and their respective dispersive energy spectra: a) and b) HAp/Eu, c) and d) HAp/Ce, e) and f) HAp/Gd.

The adsorption isotherms of pure and doped HAp are shown in Figure 6. According to the IUPAC classification, these curves can be identified as type IV isotherms, which is characterized as a mesoporous material, that is, it has pores with a diameter between 2 and $50 \mathrm{~nm}$ [28]. With regard the surface areas BET $\left(\mathrm{S}_{\mathrm{BET}}\right)$ obtained for all samples, it was verified that the $\mathrm{Eu}^{3+}$ and $\mathrm{Gd}^{3+}$ ions caused a great reduction in $\mathrm{S}_{\mathrm{BET}}$ $\left(\mathrm{HAp} / \mathrm{Eu}: \mathrm{S}_{\mathrm{BET}}=41.44 \mathrm{~m}^{2} \cdot \mathrm{g}^{-1}\right.$ and HAp/Gd: $\left.\mathrm{S}_{\mathrm{BET}}=37.95 \mathrm{~m}^{2} \cdot \mathrm{g}^{-1}\right)$ when compared to pure material $\left(\mathrm{S}_{\mathrm{BET}}=\right.$ $\left.79.09 \mathrm{~m}^{2} \cdot \mathrm{g}^{-1}\right)$. On the other hand, the $\mathrm{Ce}^{3+}$ doped matrix $\left(\mathrm{S}_{\mathrm{BET}}=74.79 \mathrm{~m}^{2} \cdot \mathrm{g}^{-1}\right)$ showed a value very close to that of pure HAp, corroborating with the XRD data. Based on these data it is proposed that the $\mathrm{Eu}^{3+}{\text { and } \mathrm{Gd}^{3+}}^{3+}$ ions may also be occupying the interstices of the crystals of HAp or influencing the decrease of the unit cell as a function of their smaller rays. 


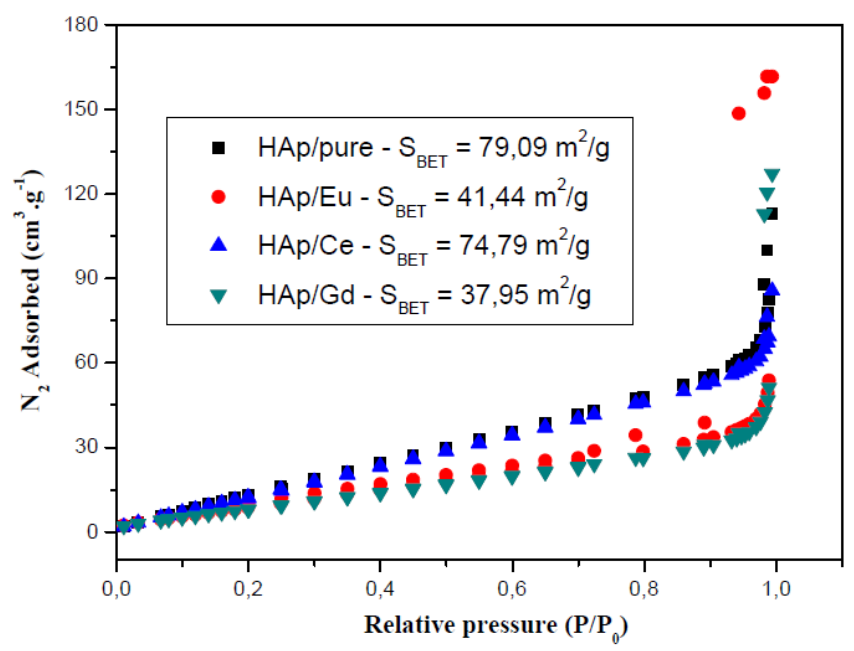

Figure 6: Nitrogen adsorption isotherms and BET surface area for pure HAp and doped with $\mathrm{Eu}^{3+}, \mathrm{Ce}^{3+}$ and $\mathrm{Gd}^{3+}$ ions.

In Figure 7, the excitation and the emission spectra for the HAp are shown. The excitation spectrum (Figure 7-a) shows a broad band with two peaks at $310 \mathrm{~nm}$ and $350 \mathrm{~nm}\left(\lambda_{\mathrm{Em}}=410 \mathrm{~nm}\right)$. The emission spectrum $\left(\lambda_{\mathrm{Ex}}=350 \mathrm{~nm}\right)$ shows a broad band with maximum $428 \mathrm{~nm}$ (Figure 7-b). In the work of ZHANG et al. [29], an emission with $\lambda_{\max }$ at $428 \mathrm{~nm}$ was also obtained for HAp microspheres, in this case, as $\mathrm{Ca}^{2+}$ ions or $\mathrm{PO}_{4}{ }^{3-}$ groups are not able to generate photoluminescence, the study of the mechanism of the HAp synthesis indicated that the observed emission was attributed to the presence of impurities or defects in the host lattice of the material. Another possibility is that this emission originates from $\mathrm{O}-\mathrm{Ca}$ charge transfer band.
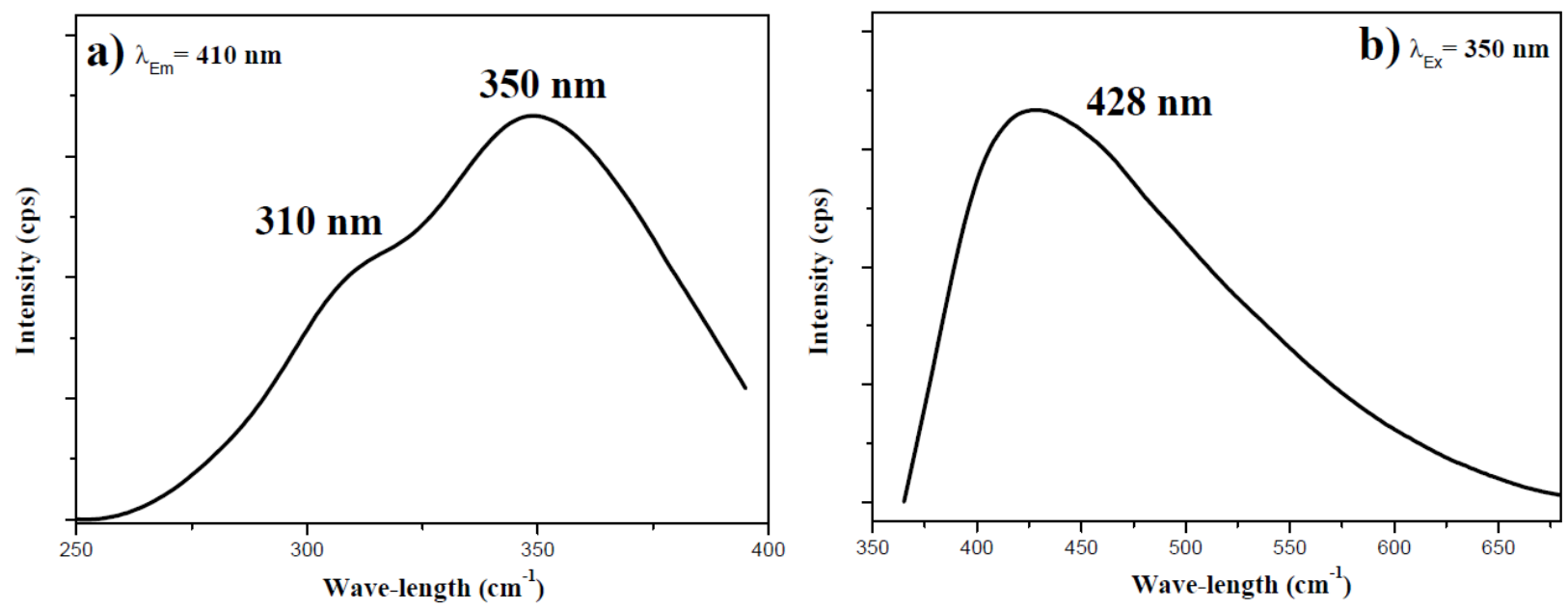

Figure 7: Spectra of a) excitation and b) emission for the matrix of Hap pure.

The HAp/Eu excitation spectra were obtained from emission monitoring at $611 \mathrm{~nm}$ $\left({ }^{5} \mathrm{D}_{0} \rightarrow{ }^{7} \mathrm{~F}_{2}\right)$ and $573 \mathrm{~nm}\left({ }^{5} \mathrm{D}_{0} \rightarrow \mathrm{F}_{0}\right)$, Figure 8-a. Both spectra present thin bands related to intraconfiguration transitions f-f. However, the excitation spectrum with emission monitoring at $573 \mathrm{~nm}$ exhibits a wide excitation band between 250 and $380 \mathrm{~nm}$, attributed to a charge transfer transition between $\mathrm{Eu}^{3+}$ and $\mathrm{O}^{2-}$ [30]. Different excitation wavelengths were used to obtain the emission spectra of the HAp/Eu sample, Figure 8-b. In these, changes in the spectral profile are verified as a function of the excitation wavelength, indicating that it is possible to selectively excite $\mathrm{Eu}^{3+}$ ions with different symmetry sites, corroborating with the results of XRD and confirming the presence of more than one phase in the material and, consequently, different chemical environments. The emission spectra, with excitation at $335 \mathrm{~nm}, 522 \mathrm{~nm}$ and $565 \mathrm{~nm}$, exhibit spectral profile with bands related to the transitions of the $\mathrm{Eu}^{3+}$ ion at: $573 \mathrm{~nm}\left({ }^{5} \mathrm{D}_{0} \rightarrow \mathrm{F}_{0}\right), 600 \mathrm{~nm}\left({ }^{5} \mathrm{D}_{0} \rightarrow \mathrm{F}_{1}\right), 622$ and $628 \mathrm{~nm}\left({ }^{5} \mathrm{D}_{0} \rightarrow \mathrm{F}_{2}\right)$. For the spectra obtained with excitation at $394 \mathrm{~nm}, 464 \mathrm{~nm}$ and $533 \mathrm{~nm}$, the most intense emission bands were observed at: $611 \mathrm{~nm}\left({ }^{5} \mathrm{D}_{0} \rightarrow \mathrm{F}_{2}\right)$ and $698 \mathrm{~nm}\left({ }^{5} \mathrm{D}_{0} \rightarrow \mathrm{F}_{4}\right)$, in addition to less intense emissions at $573 \mathrm{~nm}, 577 \mathrm{~nm}, 617 \mathrm{~nm}, 622 \mathrm{~nm}$ and $628 \mathrm{~nm} \mathrm{[21,31].} \mathrm{The} \mathrm{presence} \mathrm{of} \mathrm{Eu}^{3+}$ ions in two dis- 
tinct environments in the host matrix can be explained by the existence of two different sites for the $\mathrm{Ca}^{2+}$ ions in the crystalline structure of HAp, called $\mathrm{CaI}$ and CaII (Figure 3). The CaI site has symmetry $\left(\mathrm{C}_{3}\right)$ and the CaII site, symmetry (Cs). According to MARTIM et al. [20] $\mathrm{Eu}^{3+}$ ions preferentially occupy the Ca1 site of HAp due to the better positioning to compensate for loads between the ions; however, the sample calcination process provides thermal energy for the system, inducing diffusion of the $\mathrm{Eu}^{3+}$ ions from the $\mathrm{CaI}$ site to the CaII site from $400{ }^{\circ} \mathrm{C}$. The results agree with the migration mechanism of the ions through the matrix lattice, since the samples were calcined at $900{ }^{\circ} \mathrm{C}$ and the emissions obtained refer to the presence of $\mathrm{Eu}^{3+}$ ions simultaneously in the two different sites. The characteristic emission lines observed in the spectra show the potential for use of the material in applications linked to its photoluminescence monitoring, such as probe to investigate the degradation process of the material.
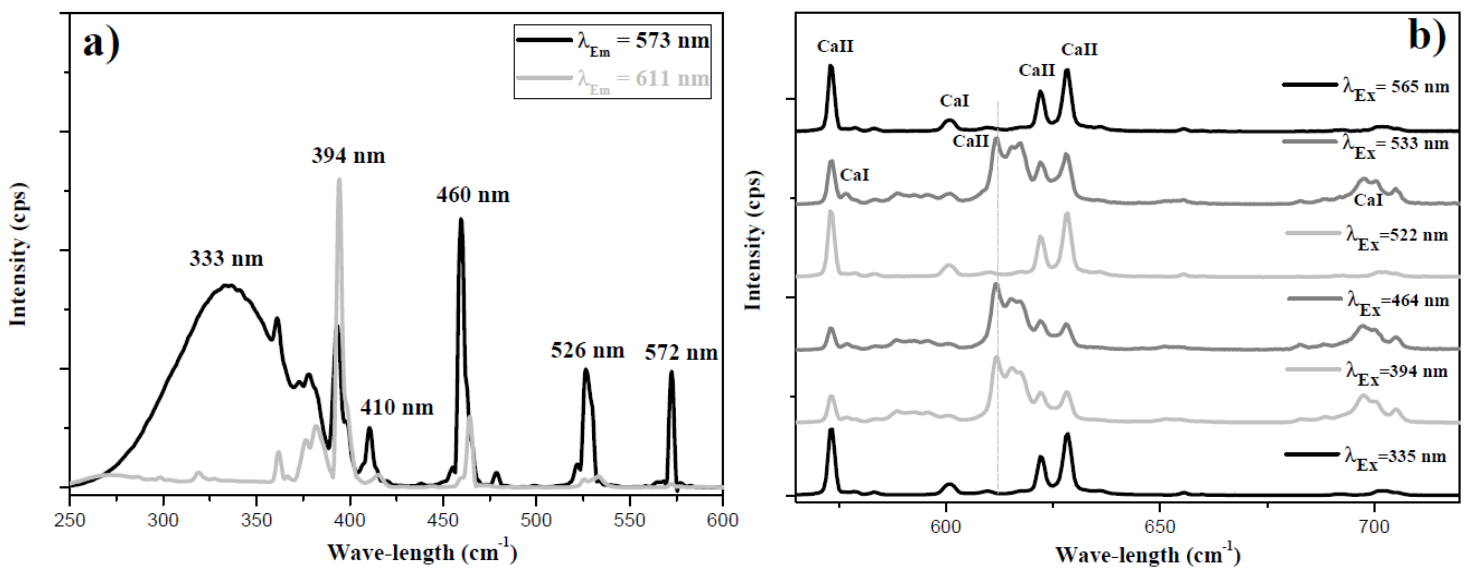

Figure 8: Spectra of a) excitation and b) emission of HAp doped with $2.0 \% \mathrm{Eu}^{3+}$ ions.

For HAp/Ce, the excitation and emission spectra are shown in Figure 9. The excitation spectra $\left(\lambda_{\mathrm{Em}}=360 \mathrm{~nm}\right)$ exhibit three bands with maxima at 268, 295 and $315 \mathrm{~nm}$. The emission spectrum shows two convoluted bands with maxima at $337 \mathrm{~nm}$ and $360 \mathrm{~nm}$, Figure 9-b. Both the emission and excitation bands are attributed to interconfiguration transitions $5 \mathrm{~d} \rightarrow 4 \mathrm{f}$ of the cerium ions. In the same way that ions $\mathrm{Eu}^{3+}$, $\mathrm{Ce}^{3+}$ ions replace the two different $\mathrm{Ca}^{2+}$ sites in the HAp lattice, in agreement with the two emission peaks observed [32].
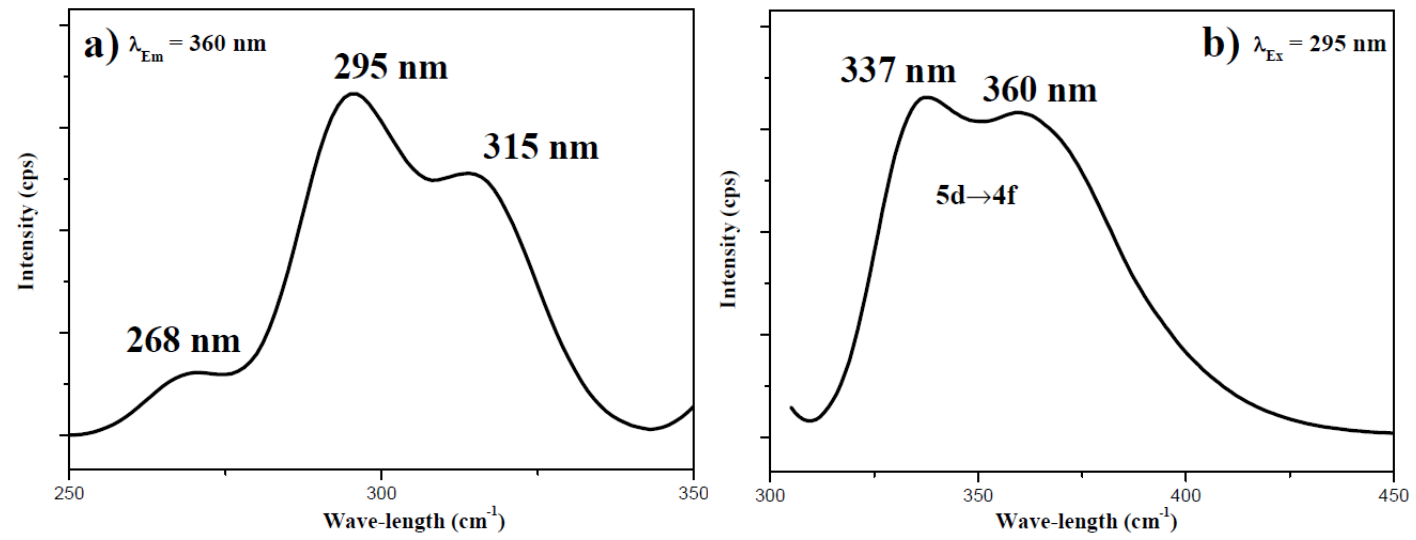

Figure 9: Spectra of a) excitation and b) emission of HAp doped with $2.0 \% \mathrm{Ce}^{3+}$ ions.

The spectra for HAp/Gd are shown in Figure 10. The material was excited using the $\lambda_{\max }$ at $343 \mathrm{~nm}$, Figure 10-a, for the acquisition of its emission spectrum shown in Figure 10-b, where it is observed a wide emission band at $425 \mathrm{~nm}$. Since the energy difference between the ground state ${ }^{8} \mathrm{~S}_{7 / 2}$ and the first excited state ${ }^{6} \mathrm{P}_{7 / 2}$ of the $\mathrm{Gd}^{3+}$ ion corresponds to the ultraviolet region [33] and the emission band observed for HAp/Gd appears in blue, this emission can be attributed to the matrix. On the other hand, it is known that gadolinium is a paramagnetic element widely used as a contrast agent in magnetic resonance diagnostics, so the incorporation of $\mathrm{Gd}^{3+}$ ions in HAp adds the image detection feature to the material [34]. 

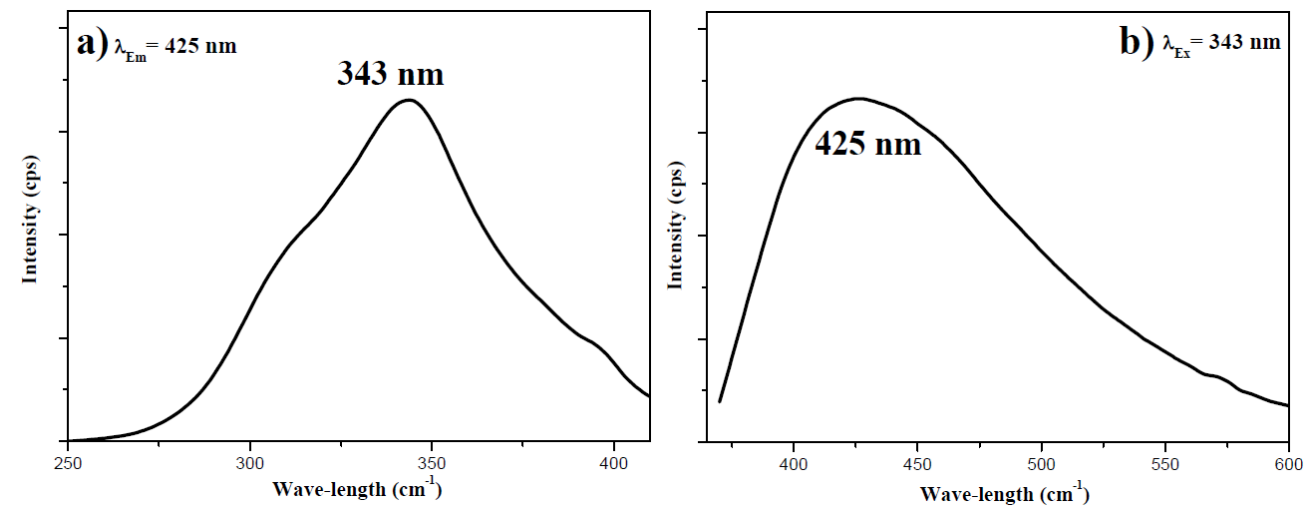

Figure 10: Spectra of a) excitation and b) emission of HAp doped with $2.0 \% \mathrm{Gd}^{3+}$ ions.

\section{CONCLUSION}

In this work, the synthesis of hydroxyapatite doped with different lanthanide ions was presented. The results obtained from the characterizations showed the complete incorporation of $\mathrm{Eu}^{3+}$ and $\mathrm{Gd}^{3+}$ ions and partial $\mathrm{Ce}^{3+}$ ions into the crystalline structure of the matrix. The material doped with $\mathrm{Eu}^{3+}$ ions indicated a great photoluminescent potential, with intense emission peaks characteristic of the europium transitions. The HAp/Ce sample also demonstrated photoluminescence brought by the $\mathrm{Ce}^{3+}$ ions inserted into the HAp, while for HAp/Gd it was suggested photoluminescence attributed to the matrix. This research demonstrated that all the lanthanide ions studied had properties that allow the generation of images of the doped HAp, as well as the obtaining of a biphasic bioceramic HAp/TCP luminescent, making these materials good candidates for application as biosensors.

\section{ACKNOWLEDGMENT}

We acknowledge to Dr. Leonis L. da Luz for helpful in the photoluminescence data aquisition.

\section{BIBLIOGRAPHY}

[1] HUGGES, J. M., RAKOVAN, J. “The Crystal Structure of Apatite, Ca5(PO4)3(F,OH,Cl)”. Reviews in Mineralogy and Geochemistry. https://pubs.geoscienceworld.org/msa/rimg/article/48/1/1/110607/the-crystalstructure-of-apatite-ca5-po4-3-f-oh-cl, v. 48 , n.1, pp. 1-12, 2002.

[2] PAN, Y., FLEET, M. E. "Compositions of the Apatite-Group Minerals: Substitution Mechanisms and Controlling Factors". Reviews in Mineralogy and Geochemistry. https://pubs.geoscienceworld.org/msa/rimg/article/48/1/13/110611/compositions-of-the-apatite-groupminerals. v. 48 (2), pp. 13-49, 2002.

[3] GOMES, D. S., SANTOS, A. M. C., NEVES, G. A., el al., "A brief review on hydroxyapate production and use in biomedicine", Cerâmica, http://dx.doi.org/10.1590/0366-69132019653742706, v. 65, pp. 282-302, 2019.

[4] MAHDAVI, J. M.; KHAYATI, G. R. "Prediction of hydroxyapatite crystallite size prepared by sol-gel route: gene expression programming approach". Journal of Sol-Gel Science and Technology, https://doi.org/10.1007/s10971-018-4601-6, v. 86, pp. 112-125, 2018.

[5] NAZEER, M. A., YILGOR, E., YAGCI, M. B., el al., "Effect of reaction solvent on hydroxyapatite synthesis in sol-gel process". R. Soc. open sci. 4: 171098. http://dx.doi.org/10.1098/rsos.171098, 2017

[6] MUBARAKALI, D. "Microwave irradiation mediated synthesis of needle-shaped hydroxyapatite nanoparticles as a flocculant for chlorella vulgaris". Biocatalysis and Agricultural Biotechnolgy, https://doi.org/10.1016/j.bcab.2018.11.025, v. 17, pp. 203-206, 2019.

[7] ASRA, D. Y., SARI, Y. W., DAHLAN, K. "Effect of Microwave Irradiation on the Synthesis of Carbonated Hydroxyapatite (CHA) from Chicken Eggshell”. IOP Conf. Series: Earth and Environmental Science, https://doi.org/10.1088/1755-1315/187/1/012016, v. 187, pp.012-016, 2018 
[8] LEE, I., LEE, J. A., LEE, J. H., HEO, Y. W., KIM, J. J. "Effects of pH and reaction temperature on hydroxyapatite powders synthesized by precipitation". Journal of the Korean Ceramic

ty, https://doi.org/10.1007/s43207-019-00004-0, v. 57, pp. 56-64, 2020.

[9] AZEVEDO, A. G de S, STRECKER, K., GORGULHO, H. F. "Effect of temperature in process of sintering of hydroxyapatite powders". Cerâmica. http://www.scielo.br/scielo.php?script=sci_arttext\&pid=S036669132015000100008, v. 61, pp. 52-59, 2015.

[10] REY, C., COMBES, C., DROUET, C., el al., "Surface properties of biomimetic nanocrystalline apatites; applications in biomaterials". Progress in Crystal Growth and Characterization of Materials, http://dx.doi.org/10.1016/J.PCRYSGROW.2014.09.005, v. 60, pp. 63-73, 2014.

[11] POMPE, W., WORCH, H., HABRAKEN, W. J. M., el al., "Octacalcium phosphate - a metastable mineral phase controls the evolution of scaffold forming proteins" J. Mater. Chem. B. https://doi.org/10.1039/C5TB00673B, v. 3, pp. 5318-5329, 2015.

[12] ZENG, H., ZHANG, L., RONG, L., el al., "A luminescent lanthanide coordination polymer based on energy transfer from metal to metal for hydrogen peroxide detection”. Internationl Journal of Biosensors \& Bioelectronics. https://www.sciencedirect.com/science/article/pii/S0956566316311654, v. 89, pp. 721-727, 2017.

[13] CANTARELli, I. X., PEDRONI, M., PICCINELli, F., MARZOLA, P., BOSCHI, F., CONTI, G., et al. "Multifunctional nanoprobes based on up converting lanthanide doped $\mathrm{CaF} 2$ : towards biocompatibile materials for biomedical imaging". Biomaterials. Sci. https://pubs.rsc.org/en/content/articlelanding/2014/bm/c4bm00119b\#!divAbstract, v. 2, 2014.

[14] SOUZA, J. M., JÚNIOR, S. A., SÁ, G. F., AZEVEDO, W. M. "Doped polymers with Ln(III) complexes: simulation and control of light colors". Journal of Alloys and Compounds. https://www.sciencedirect.com/science/article/pii/S092583880200378X, v. 344, pp. 320-322, 2002.

[15] LIMA, P. P., MALTA, O. L., JÚNIOR, S. A. "Spectroscopic study of complexes of Eu3+, Tb3+ and Gd3+ with binders derived from dicarboxylic acids". Quimica Nova.

http://www.scielo.br/scielo.php?pid=S0100-40422005000500014\&script=sci_abstract, v. 28(5), pp. 805-808, 2005.

[16] BARBOSA, A. A., JÚNIOR, S. A., FERRAZ, A. V. "Study of a luminescent and antibacterial biomaterial based on hydroxyapatite as support for an antineoplastic drug". Journal of Materials Research, https://www.cambridge.org/core/journals/journal-of-materials-research/article/study-of-a-luminescent-andantibacterial-biomaterial-based-on-hydroxyapatite-as-support-for-an-antineoplasticdrug/1249DF98088AECF269382D108D9348BA, v. 34(11), pp. 1922-1930, 2019.

[17] YANG, W. G., HA, J. H., KIM, S. G., el al., "Spectroscopic determination of alkyl resorcinol concentration in hydroxyapatite composite". Journal of Analytical Science and Technology. doi:10.1186/s40543-0160089-2, v. 7, pp.1-5, 2016.

[18] YANG, P., QUAN, Z., LI, C., KANG, X., el al., "Bioactive, luminescent and mesoporous europiumdoped hydroxyapatite as a drug carrier". Biomaterials.

https://www.sciencedirect.com/science/article/pii/S0142961208005462, v. 29, pp. 4341-4347, 2009.

[19] CIOBANU, C. S., ICONARU, S. L, MASSUYEAU, F., el al., PREDOI, D. "Synthesis, Structure, and Luminescent Properties of Europium-Doped Hydroxyapatite Nanocrystalline Powders". Journal Nanomaterials. https://www.hindawi.com/journals/jnm/2012/942801/, v. 2012, pp. 1-9, 2012.

[20] MARTIM, P., CARLOT, G., CHEVARIER, A., el al., "Mechanisms involved in thermal diffusion of rare earth elements in apatite". Jounalof Nuclear Materials.

https://www.sciencedirect.com/science/article/pii/S0022311599001269, v. 275(3), pp. 268-276, 1999.

[21] SILVA, F. R. O., LIMA, N. B., GOUVEIA, D. S., el al., Synthesis and characterization of Euopium doped hydroxyapatite: Influence of excitation wavelength on Eu3+ luminescence in HA. Material Science Forum, https://www.scientific.net/MSF.820.335, v. 820, pp. 33-340, 2015.

[22] HAN, Y., WANGA, X., DAI, H., el al., Synthesis and luminescence of Eu3+ doped hydroxyapatite nanocrystallines: Effects of calcinations and Eu3+ content. Journal of Luminescence.

https://www.sciencedirect.com/science/article/pii/S0022231312005704, v.135, pp. 281-287, 2013.

[23] LIN, K., CHANG, J. "Structure and properties of hydroxyapatite for biomedical applications. In: Hydroxyapatite (HAp) for Biomedical Applications”. 1thed. eBook ISBN: 9781782420415. 
https://www.elsevier.com/books/hydroxyapatite-hap-for-biomedical-applications/mucalo/978-1-78242-0330pp. 3-19, 2015,.

[24] ATINS, P. W., JONES, L. Principles of chemistry: questioning modern life and the environmen. 3ed. Porto Alegre: Bookman, 965 p., 2006.

[25] MORAIS, D. S., FERNANDES, S., GOMES, O. S., el al., "Novel cerium doped glass-reinforced hydroxyapatite with antibacterial and osteoconductive properties for bone tissue regeneration". Biomedical Materials. https://www.ncbi.nlm.nih.gov/pubmed/26391473, v.10(5), 2015.

[26] GYORGY, S., KAROLY, Z., FAZEKAS, P. el al., "Efeito da temperatura da reação na morfologia da HAp nanosizada". J Therm Anal Calorim, https://doi.org/10.1007/s10973-019-08255-z, v. 138, pp.145-151, 2019.

[27] KAMALANATHAN, P., RAMESH, S., BANG, L. T., el al., "Synthesis and sintering of hydroxyapatite derived from eggshells as a calcium precursor". Ceramic International.

https://www.sciencedirect.com/science/article/pii/S0272884214011080, v. 40, pp. 16349-16359, 2014.

[28] SING, K. S. W., EVERETT, D. H, HAUL, R. A. W., el al., "Reporting Physisorption Data for Gas/Solid Systems" In: Pure and Applied Chemistry.

https://www.researchgate.net/publication/244739609_Reporting_Physisorption_Data_for_GasSolid_Systems _with_Special_Reference_to_the_Determination_of_Surface_Area_and_Porosity, v. 57(4), pp. 603-619, 1985.

[29] ZHANG, C., YANG, J., QUAN, Z., el al., "Hydroxyapatite Nano- and Microcrystals with Multiform Morphologies: Controllable Synthesis and Luminescence Properties". Crystal Growth \& Design. https://pubs.acs.org/doi/abs/10.1021/cg801353n, v. 9(6), pp. 2725-2733, 2009.

[30] WANG, Y., GUO, X., ENDO, T., el al., "Identification of charge transfer (CT) transition in (Gd,Y)BO3:Eu phosphor under 100-300nm”. Journal of Solid State Chemistry.

https://www.researchgate.net/publication/223602219_Identification_of_charge_transfer_CT_transition_in_G dYBO3Eu_phosphor_under_100-300nm, v. 177(7), pp. 2242-2248, 2004.

[31] HAN, Y., WANG, X. L. I. S. "Biocompatible Europium Doped Hydroxyapatite Nanoparticles as a Biological Fluorescent Probe”. Current Nanoscience. http://www.eurekaselect.com/71370/article, v. 6(2), pp. 178-183, 2010.

[32] CIOBANU, C. S., POPA, C. L., PREDOI, D. "Cerium-doped hydroxyapatite nanoparticles synthesized by the co-precipitation method". Journal of the Serbian Chemical Society.

https://www.researchgate.net/publication/290174295_Cerium_doped_hydroxyapatite_nanoparticles_synthesi zed_by_coprecipitation_method, v. 81(4),pp. 433-446, 2016.

[33] BRITO, H. F.,MALTA, O. L., FELINTO, M. C. F. C, el al., "Luminescence phenomenainvolving metal enolates". PATAI's Chemistry of Functional Groups.

https://onlinelibrary.wiley.com/doi/10.1002/9780470682531.pat0419, 2010.

[34] CIPRESTE, M. F., PERES, A. M., COTTA, A. A. C., el al., "Synthesis and characterization of 159Gddoped hydroxyapatite nanorods for bioapplications as theranostic systems". Materials Chemistry and Physics. https://www.sciencedirect.com/science/article/pii/S0254058416304771, v. 181, pp. 301-311, 2016.

\section{ORCID}

Amanda Alves Barbosa

Severino Alves Junior

Raquel Aline Pessoa Oliveira

Andréa de Vasconcelos Ferraz https://orcid.org/0000-0003-0266-4604

https://orcid.org/0000-0002-8092-4224

https://orcid.org/0000-0002-8455-1226

https://orcid.org/0000-0001-8043-1414 